\title{
MOVING BEYOND T/V PRONOUNS OF POWER AND SOLIDARITY IN INTERACTION: PERSIAN AGREEMENT MISMATCH CONSTRUCTION
}

\section{INTRODUCTION}

Address forms contribute significantly to the marking of social relations and are thus crucial to the building and maintenance of human relationships. To date there has been limited research on how politeness is constructed in face-to-face interaction with variations in Persian address pronouns. This work aims to extend some existing research that has been conducted on the functionality of pronominal forms (Clyne et al. 2003) and the indexicality of pronouns' social meaning (Silverstein 2003).

The address pronouns will be examined by considering the concept of interface within politeness theory and interactional sociolinguistics (Brown/Levinson 1987; Gumperz 1982). Moreover, to determine how the address pronoun variation patterns index politeness, Ochs's (1992) notion of indexicality is applied. Thus, by examining the distribution of the second person pronouns to/šoma alongside other linguistic features such as enclitics and titles, a new path in the study of politeness theory and research in Persian address pronouns (i.e. a pro-drop language) is introduced.

\section{BACKGROUND}

In classical studies of address form research it is widely believed (Brown/Gilman 1960) that the choice of linguistic forms is determined by the formality of context and the relationship between interlocutors in a speech event. In sociolinguistics, a $\mathrm{T} / \mathrm{V}$ distinction describes the situation where a language has second person pronouns that distinguish varying levels of politeness, social distance, courtesy, familiarity, or insult toward the addressee. Brown and Gilman (1960) suggested that the use of the familiar pronoun $\mathrm{T}$ and deferential pronoun $\mathrm{V}$ in European languages were governed by two forces: power and solidarity. It is argued that solidarity is mostly expressed in reciprocal use of either the $\mathrm{T}$ or the $\mathrm{V}$ pronoun, while power is expressed in nonreciprocal use of pronouns between the more and less powerful in communication. The plural form is thus used as a way of expressing formality, respect or social distance. On the other hand, solidarity implies intimacy and is reciprocal. Based on this hypothesis if the interlocutors are close and intimate with each other, they will mutually exchange $\mathrm{T}$.

\footnotetext{
* Author's address: Language Centre, Hetherington Building, Bute Gardens, Glasgow G12 8RS. Email: nanbakhsh@gmail.com
} 
Clyne et al. (2003) argue that the T/V dichotomy can no longer simply be understood in terms of solidarity vs. power but through social distance relations within the theory of politeness. Secondly, Clyne et al. (2003) argue that changes in the use of address pronouns are characterised by cyclical fluctuations in time, such as the use of Swedish $n i$ to $d u$ and later to $n i$ again, which no longer follows a simple linear development as claimed by Brown and Gilman (1960). Likewise, I argue that the T/V model does not provide an accurate explanation for the mixed šma pronoun use with the second person singular verbal agreement in Persian as discussed in Section 6. The second person plural form is not necessarily always used to express formality, respect and social distance. Šoma can be used to denote appreciation and signal solidarity. I observed that solidarity can also arise from expressions of respect. Thus, šoma can be used as an address form among individuals who are intimate. Such constellations are harder to deal within a power-solidarity model.

Based on Brown and Levinson's account of politeness strategies (1987) and the notion of face (Goffman 1967), this paper investigates how politeness is performed with the variation in the use of Persian address pronouns in interaction. For example, how the interlocutors face is managed, negotiated or damaged with the variability in the use of address pronouns especially among speakers with no prior social relationships.

\section{PERSIAN ADDRESS PRONOUN PARADIGM: NULL AND OVERT SUBJECT PRONOUNS}

Persian, similar to Romance languages may be categorized as a null-subject, or a pro-drop language (word order in Persian is Subject-Object-Verb). In the case of subject position, the missing subject can be retrieved from the verb morphology, which uniquely identifies each person and number. The overt pronoun is optional in speech and when used it is mostly to show emphasis. The analysis in this paper is concerned with those contexts in which there is a choice between the two or more pronominal address forms in conversation. Persian has two personal pronouns for singular address, to the familiar or intimate "you" and šoma, the deferential or formal "you" (historically only the second person plural but now as a politeness strategy also used as second person singular). Table 1 illustrates the normative patterns of Persian pronominal address form paradigm.

\begin{tabular}{|l|c|c|c|}
\hline $\begin{array}{l}\text { Second Person } \\
\text { Pronoun }\end{array}$ & $\begin{array}{c}\text { Overt } \\
\text { pro.+agreement }\end{array}$ & $\begin{array}{c}\text { Null } \\
\text { subject+agreement }\end{array}$ & $\begin{array}{c}\text { Names/titles }+ \\
\text { agreement }\end{array}$ \\
\hline Informal & $T o+2 \mathrm{~s}$ & $\varnothing+2 \mathrm{~s}$ & Name/title+2s \\
\hline Formal & $\check{\text { Šm } a+2 \mathrm{~h} / 2 \mathrm{p}}$ & $\emptyset+2 \mathrm{~h} / 2 \mathrm{p}$ & name $/$ title $+2 \mathrm{~h} / 2 \mathrm{p}$ \\
\hline
\end{tabular}

Table 1: Persian subject and verbal agreement. 
As may be seen in Table 1 there is a possibility of variation in subject and verb agreement in Persian. For example, in subject position the address form may occur as an overt pronominal form, a phonetically null subject or as a title or a name. However, the variation paradigm in agreement position is not as diverse as the overt subject position. It allows for either the deferential (-id/-in) or the informal $(-i)^{1}$ verb agreement. The choice of different politeness levels for subject and verb agreement in speech is not merely socially-indexical but may be used to pay attention to the interlocutors' positive and negative face wants. There is limited research in Persian sociolinguistics examining the pragmatic strategies of the address pronouns and their agreement or mismatch paradigm. For example, Baumgardner (1982) only looked at the co-occurrence of the deferential address pronoun in agreement with a singular verb, but not different patterns of address form variation and their communicative strategies. Furthermore, much attention has been paid to the overt address pronouns (Keshavarz 2001), which claims that prescriptively, to is used to address inferiors in terms of age and authority, and šoma is used to express respect and distance. As a result, literature on Persian address forms have limited study of politeness of the pronominal address forms as a direct index of the forms themselves at first hand and concluded on the relevant social factors such as social distance and status between interlocutors as a determining factor in the choice of address forms.

\section{PRAGMATICS OF DEVIATION FROM LINGUISTIC NORMS OF ADDRESS}

In Persian morphology, number agreement between subject and verb is required. The plural pronouns and their agreement suffixes are used not only for plural address/referents but also for singular address/referents to indicate respect or when there is a status difference between interlocutors. However, as the analysis will show in polite speech there are cases where the overt deferential pronoun can be in agreement with singular verb agreement (šoma $\{2 \mathrm{p}\}+2 \mathrm{~s}$ verb suffix). The cooccurrence of šoma and 2 s verb agreement, which we will call a "mismatch", is underlined in Example 1.

1)

šma zud mi-ya-i bala?

$2 \mathrm{p}$ quick dur-come- $2 \mathrm{~s}$ yes

"You will come soon, right?"

The mismatch construction is deviant in interaction. This communicative strategy manifests attention paid to both speaker and hearer's positive and negative face wants. To date there has been limited research in conversational Persian focusing on the

1 The deferential verbal agreement (-id) is coded as $2 \mathrm{~h}$ showing great deference and (-in) is coded as $2 p$ indexing politeness not necessarily deference. The singular verbal agreement (-i) is coded as $2 \mathrm{~s}$ in the data. 
communicative strategies performed by the mismatch construction. Sociolinguistic studies in other languages offer evidence of instances of agreement mismatches in politeness levels can be found in languages such as Hindi (Jain 1973), Spanish (Kany 1951) and Brazilian Portuguese (Head 1976). For instance, Head's (1976) study on the second person pronoun concluded that regional, social variation and the relationship between interlocutors is the main conditioning social variable in the choice of addressee pronoun.

\section{DATA AND METHODS}

Two sets of data were collected for the purpose of the analysis: audio-recordings of ten hours of spontaneous media conversations representing address pronoun usage among people with no prior social relationships and open-ended informal interviews with twenty individual informants (among family and friends) to obtain folk views of address form usage in contemporary Persian.

The media corpus is recorded from channel Two of national Iranian television $\mathrm{http}: / / \mathrm{tv} 2$.irib.ir, collected in a field trip to Iran in summer 2007. This programme, aez maen ta ma "From me to we", aims at raising awareness of the moral, social and economic dilemmas of society at large. It shows how to change from just thinking about oneself in society to a communal understanding of existing social problems. This data draws on examples of address form usage from conversation with 115 participants (Male: 90, Female: 25) categorised in three estimated age groups: ${ }^{2}$ young (c. 35 or under), middle aged (c.36-55 years) and old (c.56-80 years). Each episode is a programme with two sections, a hidden camera followed by an interview with the presence of a camera. With diversity of social interactions occurring among different age groups and across both genders, the spontaneous media conversations in this study provide a better picture of how language and politeness is used in different social contexts.

The feature of hidden camera provides a situation where the participants interact spontaneously. In the interviews, the interlocutors interact spontaneously, since the interviewer interrogates them unexpectedly. One might argue that media extracts involve the staging of interactions by professionals, who in a sense attempt to entrap passers-by into participating in a pre-planned interaction sequence. In order to rectify this issue, I have researched this matter and consulted with members from Iranian broadcasting programme. The producer of this programme (Taghavi-Zonouz 2010) mentioned that the improvised actor and the interviewer's speech are not scripted nor staged. The improvised actor and interviewer are just given a theme of what topic to talk about. There is also empirical evidence for this as both the improvised actor and the interviewer use different strategies in addressing each pedestrian. The data cannot be staged nor scripted as the use of pronouns of address is conditional on the

\footnotetext{
${ }^{2}$ As the episodes in the hidden camera and interview programme are spontaneous interactions therefore the indicated interlocutor's ages are estimates and are assessed on the basis of appearance and voice.
} 
interaction of both interlocutors in the sequence of face-to-face interactions. Interviewer and improvised actors are not aware of what stances the pedestrians may take in response to their speech. This study contrasts with previous research on media television sitcoms (e.g. Quaglio 2009), where the interactions are predetermined.

To analyse data qualitatively, the methodology employed is based on interactional sociolinguistics (Gumperz 1982), with discourse analysis of sequences of talk. Thus, in order to investigate the functions of address pronouns in practice, it is essential to observe many interactions between participants from the target community. Furthermore, the content analysis ${ }^{3}$ (Gillham 2000) of the open-ended interviews provides a clear picture of individuals' perception and attitudes towards the patterns of address pronoun usage in interaction. The ongoing interactions were investigated with the concept of face, stance and indexicality. Indexicality refers to the fact that "the understandability of any utterance, rather than being fixed by some abstract definition, depends upon the circumstances in which it appears" (Maynard/Clayman 1991: 397). Ochs (1992: 335) discusses two possible indexing strategies: "direct" referential and "indirect" constitutive indexing. In other words, indexicality indicates which cultural contexts, such as social identities (e.g. gender) and social activities (e.g. gossip), are constituted by a particular stance and acts in speech.

Stance is defined from a varied range of perspectives: individual, social, contextual and interactional or an amalgam of these social and individual roles. Accordingly, analysts of discourse in interaction (Gumperz 1982; Ochs 1992) account "stance" for how particular linguistic choices in interaction accomplish social and rhetorical actions. In this line Kiesling (2009) argues that "stancetaking is the main constitutive social activity that speakers engage in when both creating a style and style-shifting" (Kiesling 2009: 314).

In the course of the following discussion, I will argue that the sociolinguistic functions of agreement mismatch construction is constituted and mediated indirectly by the relation of language to speaker and interactional stances, social activities, and other social dimensions such as power, status and age.

\section{RESULTS AND ANALYSIS}

This section casts new light on how the agreement mismatch construction and its variation are used as communicative strategic devices. One sometimes finds mismatches such as singular verb agreement with šoma, apparently to "soften" the formality. However, the singular agreement is not always used as a solidary social function. The analyses show that the sociolinguistic function of the agreement mismatch construction varies according to speaker and interactional stances. The claim, challenge, or negotiation of power and status between speakers is marked with the hybrid style of the deferential and informal address pronouns in interaction. In

${ }^{3}$ In order to ensure the participants confidentiality in the open-ended interviews, pseudonyms have been used. 
speech, the agreement mismatch has an emphatic role that may indirectly index assertion of status and lobbying when one takes a begging or bribing stance respectively.

\subsection{Pattern 1: $\varnothing+2 \mathrm{~h}-\rightarrow \varnothing+2 \mathrm{p}-->$ šoma $+2 \mathrm{~s}$ (indexing asserting status)}

In this interaction between the beggar (B1) and pedestrian (G), power and status difference is indexed with the interlocutor's asymmetrical pronoun use. This pattern is clearly highlighted in the beggar's speech style which also includes the mismatch construction.

2)

[Programme: "Beggar", Setting: Hidden Camera, Speakers: B1: Beggar, M., c.45 - G:

Pedestrian, M., c.65]

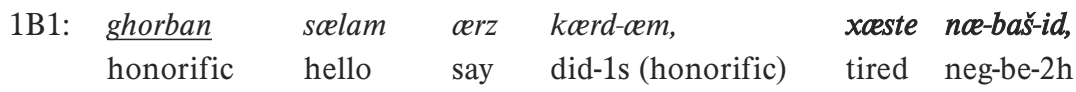
"Your Excellency hello? don't be tired"

2 mi-xast-æm ye xaheš-i bo-kon-cem dur-want-1s one desire-ind. subj-do-1s

"I wanted to ask you a favour"

3G: noe, noe-kon <with loud agressive voice> no neg-do.2s "no, don't"

4B1: ye nosxcest, lotf be-forma-yin ind prescription please imp-do-2p (honorific) "it is a prescription, if you could kindly"

5G: mi-dun-cem či mi-xah-i be-g-i nae-dar-cem dur-know-1s what dur-want-2s sub-say-2s neg-have-1s "I know what you want to say, I don't have any (money)"

6B1: maen axe čiz-i noe-goft-cem ke be šoma, "but I didn't tell you anything"

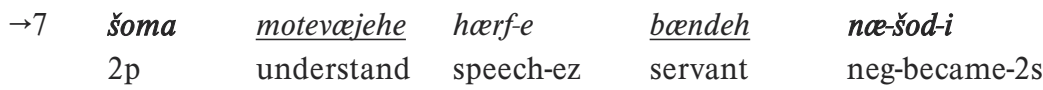
"you didn't understand what I said"

$\rightarrow 8 \mathrm{G}: \quad x o b$ be-go be-bin-cem č $c$ mi-gi $i \uparrow$ ok imp-say.2s subj-see-1s what dur-say-2s $\uparrow$ "ok, say what you want to say"

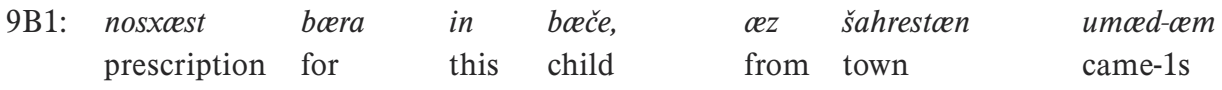
"it is a prescription for this child, I have come from town"

The beggar initiates the conversation by greeting the pedestrian, where three honorific linguistic features are used: title ghorban "your Excellency", a verb saelam aerz kaerdaem "I say hello" and a deferential agreement naebašid "don't be" (line 1). In Persian, 
these politeness features are considered as ta'arof $^{4}$ and used frequently between strangers to establish a relationship. However, due to beggar's inferior social role and his dodgy request, this style of language use may be categorised as čarb zæebani "sweet talk", to flatter the hearer. Thus in line 1, the beggar used self lowering and other raising linguistic markers and expressions to redress the negative imposition of his request on the hearer's face needs. However, B1 is confronted with G's negative response (lines 3 and 5 respectively), which covertly delineates his inferior social role. In line 3 , the informal agreement (2s) conjugated on a negated imperative verb noekon "don't" follows a negation nce "no", forming a double negation which serves to increase the perceived distance from the addressee. Asymmetrical use of address forms between B1 and G can also be seen in lines 4 and 5 where the pedestrian further delineates the beggar's status by overtly stating he knows what the beggar is after. Interestingly, the beggar switches to the mismatch construction (line 7) to take control in the conversation. He uses the deferential overt pronoun, and a negated imperative verb marked with a singular agreement forming a mismatch construction, which indexes the claiming of status and power in the interaction. Furthermore, the beggar's use of honorific self reference baendeh "I" is evidence of the assertion of power and status in the conversation. So the pedestrian gives him the floor in the conversation (line 8).

According to this example, the mismatch construction is to show both contradiction and emphasis toward the stance and discussion in the interaction. That is, it indexes giving status to the speaker rather than the hearer. With regard to the emphatic social function of šma in interaction, the construction of šma with a singular agreement is to raise the hearer's attention of his irresponsible action. This is further accompanied by the switch between the singular and deferential form. In the following interaction, we can see that the mismatch agreement construction functions as a positive politeness strategy.

\subsection{Pattern 2: $\emptyset+2 \mathrm{~h} \mathrm{-->} \mathrm{šoma}+2 \mathrm{~s}-->\varnothing+2 \mathrm{~s}$ à šoma $+2 \mathrm{~s}$ (indexing lobbying)}

Partibazi "lobbying" in Iran deals with the representation of individual interests to persons with the power to grant privileges of various sorts: employment, licences and exemptions from certain laws, etc. (Binder 1962: 255). In the following interaction, the bribery is a form of partibazi, which involves exemption to the law of registration in a public school. As bribing somebody in return for a favour is considered a suspect on-record action, it may threaten the addressee's negative face wants. Thus it is expected that deference in speech style is used in order to hedge the imposition of this act. The conversation in Example 3 occurs between a parent (C) and a suborner (B) in a school. There are various pronoun switches and the mismatch construction in B's speech in order to notify and convince C to bribe him. These switches and mismatches can be seen at all levels of pronoun usage (address forms, enclitics and agreement), as well as verb stems.

\footnotetext{
${ }^{4}$ Ta'arof is an important aspect of politeness in the Persian language and culture. The word ta'arof is defined as a kind of welcoming, praising, and presenting (Dehkhoda 1966).
} 
3)

[Episode: "Bribe", Setting: Hidden Camera, Speakers: B: Suborner, M., c.45 - C: Parent, M., c.40]

\begin{tabular}{|c|c|c|c|c|c|}
\hline 1B: & $\frac{\text { kon-aem }}{\text { do-1s }}$ & $\begin{array}{l}\text { huzur-e-tun } \\
\text { prescence-ez-2p.cl }\end{array}$ & $\begin{array}{l}\text { moen } \\
1 \mathrm{~s}\end{array}$ & $\begin{array}{l}\text { mi-tun-cem } \\
\text { dur-can-1s }\end{array}$ & $\begin{array}{l}\text { kari } \\
\text { job-ind }\end{array}$ \\
\hline & \multicolumn{5}{|c|}{ "may I say that I can be of help" } \\
\hline 2 & $\begin{array}{l}\text { baera-tun } \\
\text { for-2p.cl }\end{array}$ & $\begin{array}{l}\text { o-kon-cem inja, } \\
\text { ubj-do-1s here }\end{array}$ & $\begin{array}{l}\text { agar } \\
\text { if }\end{array}$ & $\begin{array}{l}\text { mayel } \\
\text { like }\end{array}$ & $\begin{array}{l}\text { hoest-id } \uparrow \\
\text { is- } 2 \mathrm{~h}\end{array}$ \\
\hline
\end{tabular}

"here for you if you like $\uparrow$ "

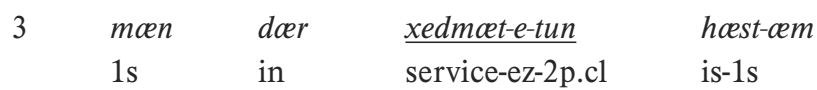

"I am at your service"

4C: xaheš mi-kon-cem, emsal ma noezdiktoer hoest-im <inaudible> please dur-do-1s this year $1 \mathrm{~s}$ near is-1p

"thank you, this year we are closer (to this school)"

$\rightarrow 5 \mathrm{~B}$ : čon šoma mayel hoest $i$, inke ma doer xedmat-e-tun-im beacuse $2 \mathrm{p}$ fond is- $2 \mathrm{~s}$ that $1 \mathrm{p}$ in service-ez-2p.cl-1p "as you are inclined, I am at your service"

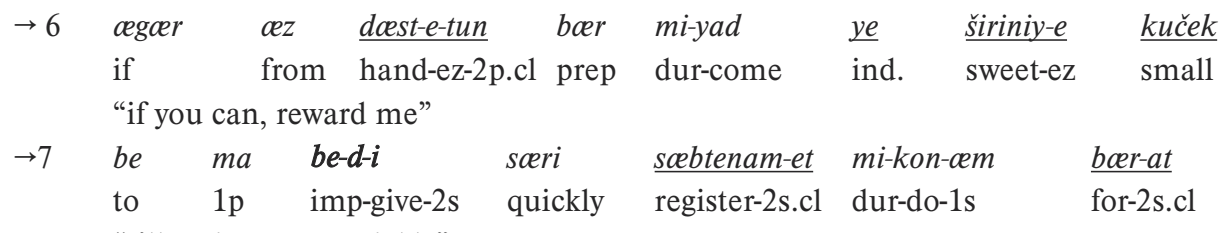

"I'll register you quickly"

8C: xaheš mi-kon-aem

please dur-do-1s

"thank you"

9B: moškeli na-dar-i?

problem neg-give-2s?

"is that OK?"

10C: nae moškel noe-dar-aem

no problem neg-have-1s

"no, that's not a problem"

11B: noe moškel nae-dar-i širini mi-d-i?

no problem neg-have-2s sweet dur-give-2s?

"don't you have any concern to reward me?"

12C: širini mi-d-cem, hala čegadr mi-xah-i?

sweet dur-give-1s now how much dur-want-2s?

"I'll give you a reward. Now, how much do you want?"

13B: čegcedr dust dar-i, šoma hoem razi ba-š-i dege how much like have- $2 \mathrm{~s} 2 \mathrm{p}$ also satisfy imp-be-2s else "whatever you like. Well, you should be happy with it too"

14C: xaheš mi-kon-am 
please dur-do-1s

"thank you"

In this interaction, B is offering to register C's child in a public school ${ }^{5}$ in return for money. Interestingly in line 1-3, the suborner uses the honorific speech style in greeting C. This includes a) honorific verbs oerz koncem "I say", b) deferential agreement -id (2h) mayel hoestid "if you like", and c) plural enclitics -tun (2p). While $\mathrm{C}$ welcomes B's offer with discourse marker xaheš mikoncem "you are welcome", in line 5 the suborner avoids the use of the deferential verb agreement and switches to the use of: a) a mismatch construction, and b) informal verbal agreement bedi "give me", and enclitics saebtenamet "register 2s.cl". In this informative stance, šoma emphasises the addressee's role and relation in the interaction, to ensure that $\mathrm{C}$ is happy to bribe $\mathrm{B}$ and take the responsibility of this action; by softening the formal agreement to mismatch, B shows solidarity. Moreover, to accommodate with C's plural self referent form $m a$ "we", B switches to the first person plural overt pronoun and agreement (line 5) and then he switches back to first person singular agreement in line 7. Within the same utterance, we can see variation of first person agreements: plural-im (line 5)/singular-am (line 7), and second person enclitics: singular xedmaetet/plural xedmeetetun. This shows the ambivalent nature of how pronouns may be used to accommodate to the situational needs of the interaction (Ervin-Tripp 1972).

In colloquial Persian, use of the full form of "to be" verb hoest ${ }^{6}$ gives a formal flavour to the interaction. It should also be mentioned that $2 \mathrm{~s}$ occurs with a deferential form of the "to be" verb hoest (line 5). This constitutes a mismatch, though a different kind to the pronoun-agreement mismatches that we have mainly discussed until now. These kinds of mismatches between verb stems and inflection show that in general people use mismatches to serve different sociolinguistic purposes. In this interaction, establishment of negotiation and solidarity is marked by use of reciprocal informal agreement forms between both parties. As we observed, the use of mismatch construction may also index intensification of role and relationship between interlocutors, in other words partibazi "lobbying".

Qualitative analysis of the mismatch construction revealed that incongruent use of address form and agreement may be considered as a communicative strategy to mitigate the power and status differences in face-to-face interaction. As the mismatch construction consists of šoma and a singular agreement, we might expect it to index a hybrid pragmatic function in communication. The communicative function of agreement mismatch may vary according to the speaker's stancetaking in the conversation and may serve as either a positive or a negative politeness strategy. Therefore, the mismatch construction in interaction is used as a turning point or a "transition stage" in the social dimensions of speech such as power or solidarity.

\footnotetext{
${ }^{5}$ Registration with public school requires being resident in the catchment area.

6 The infinitive hoestcen "to be" has a written form (hoest) and in the colloquial form, verbal agreement is used.
} 


\section{Community view}

Content analysis of the sociolinguistic interviews reveals little awareness among individuals of the deviant uses of the Persian pronominal address system. The interviewees were asked when and why they use the mismatch construction in conversation. They either diverged from the question by providing an irrelevant answer or paused in surprise at the idea that they used the address pronouns in such ways. Among all the interviewees I spoke to, only two female speakers showed awareness of the use of the mismatch construction. In the first case, the interviewee denoted generational change in the use and function of the mismatch construction. This was mentioned in an interview with Niloufar (female, 40 year, teacher), as translated here:

4)

Author:

"What effect do you see in the use of a deferential pronoun in agreement

with a singular verb?"

Niloufar:

"Cultural, moral and speech style differences between young and old generation is the main reason for the mismatch construction usage. The young generation use more singular informal to pronoun and this is in a form of second person singular. And that if changes [cultural, political] occur people use a deviant form such as 'what did you(2p) do(2s)"'.

In the second case, Shila (female, 45 year, nurse) shows that how the mismatch construction can be used as a tool to reduce distance or to show deference.

5)

Author:

"What does the use of a deferential pronoun in agreement with a singular verb show?"

Shila:

"It shows that the speaker doesn't know whether to be close to his/her addressee or not, the speaker doesn't know whether to maintain the closeness when he/she switches in the verb and says 'come(2s)', [or] when he/she says 'come(2p)', keeps distance from the addressee and this results in a loss of an intimate mood."

This re-conceptualisation of the deferential form of address in interaction may result in hybrid function, combining deferential and casual indexes. As a result, the mismatch construction shows the versatility of the Persian address system.

\section{CONCLUSION}

This study argued that in order to provide a cognitive account of address form variation patterns, we need to consider these forms in the context of the interaction, and identify how they may index communicative strategies in different stances. It discussed the dynamicity of Persian address forms and politeness. Variation patterns 
observed in the Persian address system contributes to our better understanding of the versatility of the pronominal forms of address and the multifarious politeness strategies in face-to-face interaction.

The interactional analysis showed that the versatile forms the pronouns of address take function as an asset for mitigating behaviours in interaction. The dynamicity of form and function of politeness features in Persian provides a web of strategies of how complex and yet systematic language may function. The conducted interviews show that individuals are only aware of the prescribed attributes of address pronouns which they have acquired in formal education not their pragmatic or interactional properties (i.e. agreement mismatch construction). The occurrences of agreement mismatches are not random but strategic that serve communicative goals below individuals conscious awareness. These hybrid patterns show that in practice address forms are not constrained to the existence of social relationship but in turn are an asset in developing acquaintance in the moment of interaction and index transition of interpersonal and interactional stances. Thus, the communicative strategies indexed with address pronoun variation patterns themselves are not quantifiable as each strategy is dependant on the stance in the interaction. In sum the address pronoun variation paradigm in the Persian language offers a unique and interesting aspect of the human communication system.

\section{Primary sources:}

BAUMgardner, Robert J. (1982) Sociolinguistic aspects of Persian pronouns of address: a macro/micro analysis. Los Angeles: University of Southern California.

Brown Penelope/Stephen Levinson (1987) Politeness: Some universals in language usage. Cambridge: Cambridge University Press.

BRown Roger/Albert GiLman (1960) "The pronouns of power and solidarity." In: T. A. Sebeok (ed), Style in Language. Cambridge: MA: MIT Press Cambridge, 253-276.

Clyne Michael/Heinz L. KretzenbaChER/Catrin NorrbY/Jane WARren (2003) Address in some Western European languages. Proceedings of the 2003 Conference of the Australian Linguistics Society. 10 May 2012.

http://www.als.asn.au/proceedings/als2003/clyne.pdf.

ERvin-Tripp, Susan M. (1972) "Sociolinguistic rules of address". In: J. B. Pride/J. Holmes (eds), Sociolinguistics. Harmondsworth: Penguin, 225-240.

Gillham, Bill (2000) Case Study Research Methods. London: Continuum.

GoFFMAN, Erving (1967) "On facework: an analysis of ritual elements in social interaction." In: A. Jaworski/N. Coupland (eds), The Discourse Reader. London, Routledge, 306-321.

GuMPERZ, John J. (1982) Discourse Strategies. Cambridge: Cambridge University Press. HEAD, Brian F. (1976) "Social factors in the use of pronouns for the addressee in Brazilian Portuguese." In: J. Schmit-Radfeldt (ed), Readings in Portuguese linguistics. Amsterdam: North-Holland, 289-348.

JAIN, Dhanesh (1973) Pronominal usage in Hindi. Philadelphia: University of Pennsylvania. KanY, Charles (1951) American Spanish Syntax. Chicago: University of Chicago press. 
Keshavarz, Mohammad H. (2001) "The role of social context, intimacy, and distance in the choice of forms of address." International Journal Social Language, 148: 5-18.

Quaglio, Paulo (2009) Television dialogue: the sitcom Friends vs. natural conversation. Amsterdam/Philadelphia : John Benjamins.

SiLVERSTEIN, Michael (2003) "Indexical order and the dialectics of sociolinguistic life." Language and Communication 23/3-4, 193-229.

\section{References}

BINDER, Leonard (1962) Iran: Political Development in a Changing society. Berkely/Los Angeles: University of California press.

MaYnaRD, Douglas W./Steven E. Clayman (1991) "The diversity of ethnomethodology." Annual Review of Sociology 17, 385-418.

Ochs, Elinor (1992). "Indexing gender". In: A. Duranti/C. Goodwin (eds), Rethinking context. Cambridge: Cambridge University Press, 325-358.

KiesLing, Scott F. (2009) "Style as Stance: Stance as the explanation for patterns of sociolinguistic variation.” In: J. A. Stance (ed), Sociolinguistic Perspectives. Oxford: Oxford University Press, 171-194.

\section{Appendix}

$\begin{array}{ll}\text { Morphological } & \text { glossary } \\ \text { agr } & \text { agreement } \\ \text { assoc } & \text { associative marker (-ina) } \\ \text { cl } & \text { classifier } \\ \text { comp } & \text { complementiser (ke) } \\ \text { def } & \text { definite marker (-æ) } \\ \text { dur } & \text { durative marker (mi-) } \\ \text { ez } & \text { the Ezafe vowel (-e) } \\ \text { imp } & \text { imperative } \\ \text { ind } & \text { indefinite marker (-i) } \\ \text { infl } & \text { inflection } \\ \text { neg } & \text { negative marker (næ-, ne) } \\ \text { om } & \text { object marker (-ro, -o) } \\ \text { part } & \text { participle } \\ \text { sg } & \text { singular } \\ \text { pl } & \text { plural } \\ \text { pres } & \text { present } \\ \text { subj } & \text { subjunctive marker (be-) } \\ \text { pro } & \text { pronoun } \\ \text { 1s.cl, 2s.cl } & \text { pronominal possessive enclitics } \\ \text { 2s } & \text { second person singular } \\ \text { 2h/(2p) } & \text { second person plural } \\ 3 \mathrm{p} & \text { third person plural } \\ & \end{array}$




\title{
Transcription notation
}

\section{Character Format}

Italics

Transcription for Persian utterances

Bold Emphasis for transcription of Persian utterances

Normal Syntactic transliteration and English translation of Persian utterances

Underline To highlight linguistic features other than address form in speech

\section{Symbols}

$\begin{array}{ll}(\quad) & \text { Indicates unclear speech } \\ (.) & \text { A pause between utterances } \\ : & \text { Lengthened sound/syllable } \\ {[} & \text { Overlap } \\ <> & \text { Material that is not part of talk being transcribed (e.g. laughter, loud } \\ & \text { aggressive voice) } \\ & \text { Indication of higher pitch } \\ & \text { Marking transition point in address form usage }\end{array}$

\section{Abstract \\ MOVING BEYOND T/V PRONOUNS OF POWER AND SOLIDARITY IN INTERACTION: PERSIAN AGREEMENT MISMATCH CONSTRUCTION}

\begin{abstract}
Research on Persian pronominal address forms (to the intimate "you" represented as "T" after French $t u$ and šoma the deferential "you" similar to French vous represented as "V", historically plural but now also used as singular) has been limited to questionnaire data with a simplistic analytical model of $\mathrm{T} / \mathrm{V}$ distinction. This paper documents the communicative strategies indexed by agreement mismatch construction (e.g. the mixed šoma pronoun use with the second person singular verbal agreement). The qualitative analysis is based on a corpus of interactional data and open-ended interviews to explain variations observed in the Persian pronominal address system. Strategic use of agreement mismatch construction suggests that politeness in address forms could be based on interlocutors stancetaking in negotiating relationships.
\end{abstract}

Keywords: politeness, address pronouns, pro-drop, stancetaking, indexicality, Persian.

\section{Povzetek \\ RAZŠIRJENA VLOGA ZAIMKOV TIKANJA IN VIKANJA PRI IZRAŽANJU MOČI IN SOLIDARNOSTI: MEŠANE STRUKTURE V PERZIJSKEM JEZIKU}

Obstoječe raziskave zaimkov naslavljanja v perzijskem jeziku so bile večinoma izvedene $\mathrm{s}$ pomočjo vprašalnikov o rabi in slonijo na poenostavljenem analitičnem modelu T/V (kategorijo "T" v perzijščini predstavlja to (ti), vljudnostno kategorijo "V" pa šoma (vi)). Pričujoči prispevek se osredotoča na analizo komunikacijskih strategij pri rabi mešane konstrukcije (vikanje z 
zaimkom šoma v kombinaciji z glagolom v drugi osebi ednine). Analiza je osnovana na korpusu interaktivnih pogovorov in odprtih intervjujev, njeni rezultati pa razlagajo variantnost dejanske rabe perzijskega sistema naslavljanja. Strateška uporaba mešane konstrukcije namreč kaže, da je vljudnost pri naslavljanju lahko odvisna od pogajalskega odnosa med govorcema.

Ključne besede: vljudnost, zaimki naslavljanja, izpust zaimka, naravnanost, znakovnost, perzijščina. 